\title{
Osteomalacia due to Vitamin D Deficiency: A Case Report
}

\author{
D Vitamini Eksikliğine Bağlı Osteomalazi: Olgu Sunumu \\ (1) Banu Ordahan, (1) Kaan Uslu, (1) Hatice Uğurlu
}

Necmettin Erbakan University Meram Faculty of Medicine, Department of Physical Medicine and Rehabilitation, Konya, Turkey

\section{Abstract}

Osteomalacia is a metabolic bone disease characterized by demineralization of the newly formed osteoid in adults. Vitamin D deficiency due to insufficient vitamin $D$ intake, inadequate exposure to sunlight, and malabsorption of vitamin $D$ are the most widespread cause of osteomalacia. Here,we present the case of 18 year old female patient who presented to our hospital with complaints of low back pain. Sacral bone pseudofracture was detected by magnetic resonance imaging due to osteomalacia. Patient was treated with vitamin $\mathrm{D}$.

Keywords: Osteomalacia, vitamin D deficiency, pseudofracture

\section{Öz}

Osteomalazi, yetişkinlerde yeni oluşan osteoidin mineralleşmesinde azalma ile karakterize metabolik bir kemik hastalığıdır. Yetersiz D vitamini alımı, güneş ışığına yetersiz maruz kalma ve D vitamini malabsorpsiyonu nedeniyle D vitamini eksikliği, osteomalazinin en sık nedenidir. Bu yazıda, bel ağrısı şikayeti ile hastaneye başvuran 18 yaşında kadın hastayı sunduk. Osteomalazi nedeniyle manyetik rezonans görüntüleme ile sakral kemik psödofraktürü saptandı. Hasta D vitamini ile tedavi edildi.

Anahtar kelimeler: Osteomalazi, D vitamini eksikliği, psödofraktür

\section{Introduction}

Osteomalacia is a metabolic bone disease identify by a decrease in the mineralization of the newly formed osteoid in adults. Mechanisms that result in hypocalcemia, hypophosphatemia, vitamin D metabolism disorders, or direct inhibition of the mineralization process cause osteomalacia (1).

Osteomalacia should be suspected in cases of malabsorption, gastric bypass surgery, celiac disease, chronic liver disease, or bone pain due to chronic kidney disease.

The diagnosis is based on a combination of clinical features (bone pain and tenderness, fractures and/or muscle weakness), laboratory results, radiologic findings, and rarely, transiliac bone histomorphometry (1-3). Vitamin D deficiency due to insufficient vitamin $D$ intake, inadequate exposure to sunlight, and malabsorption of vitamin $D$ is the most widespread cause of osteomalacia (1-3).

\section{Case Report}

An 18-year-old female refugee patient presented to our outpatient clinic with low back pain and legs pain. The patient, who was seen by the neurosurgery department because of low back pain, was diagnosed as having spondylolisthesis at the L5-S1 level and was given a lumbosacral steel corset. There was no regression in the patient's pain. The patient described having difficulty in walking with low back pain and legs pain, and difficulty in walking up and down stairs. On physical examination, the range of motion of the lumbar joint was complete, deep tendon reflexes were normoactive, there was no sensory defect and pathologic reflex. Trendelenburg gait was markedly observed. Lumbosacral radiography revealed no spondylolisthesis. In laboratory tests, the hemogram was normal; glucose, urea, creatinine, aspartate transaminase, and alanine transaminase were normal; alkaline phosphatase (ALP) was $1479 \mathrm{U} / \mathrm{l}$, calcium (Ca) was $8.88 \mathrm{~g} / \mathrm{dL}$, phosphorous (P) was $1.95 \mathrm{mg} / \mathrm{dL}$, parathyroidhormone (PTH) was $449 \mathrm{pg} / \mathrm{mL}$, 25-hydroxy vitamin D [25(OH)D] was $3 \mathrm{ng} / \mathrm{mL}$, and the 24-hour urine Ca was $25 \mathrm{mg}$. There were multiple stress fractures in the magnetic resonance imaging (MRI) of the sacral region of the pelvis (Figures 1a, 1b, 1c).

The patient was diagnosed as having osteomalacia as a result of the detection of common pain, typical Trendelenburg gait pattern, low Ca, P, and 25(OH)D, high ALP, low 24-hour urinary

Address for Correspondence/Yazışma Adresi: Banu Ordahan MD, Necmettin Erbakan University Meram Faculty of Medicine, Department of Physical Medicine and Rehabilitation, Konya, Turkey

Phone: +90 5058741256 E-mail: banuordahan@gmail.com ORCID ID: orcid.org/0000-0003-2221-2728 Received/Geliş Tarihi: 19.09.2019 Accepted/Kabul Tarihi: 16.04.2020

${ }^{\circ}$ Copyright 2020 by the Turkish Osteoporosis Society / Turkish Journal of Osteoporosis published by Galenos Publishing House 


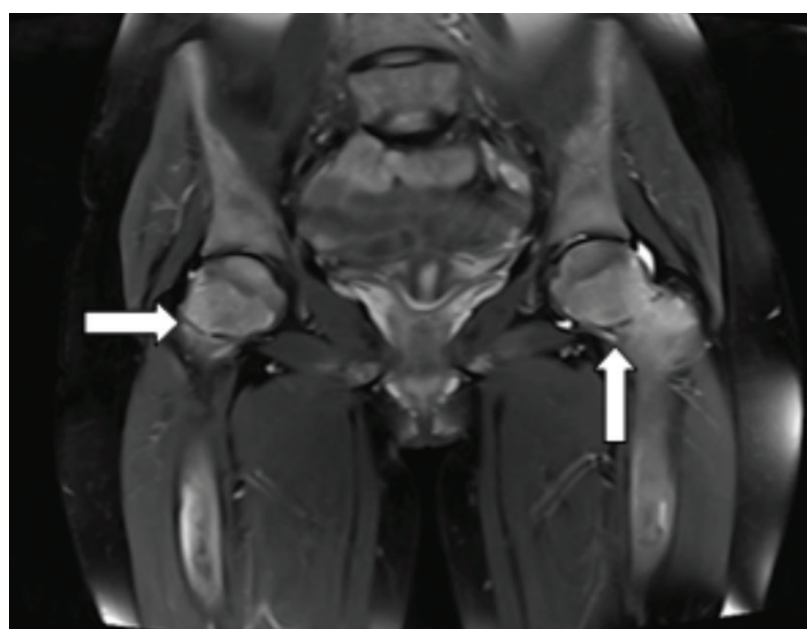

Figure 1a. Magnetic resonance coronal T2- weighted Fat-Sat image

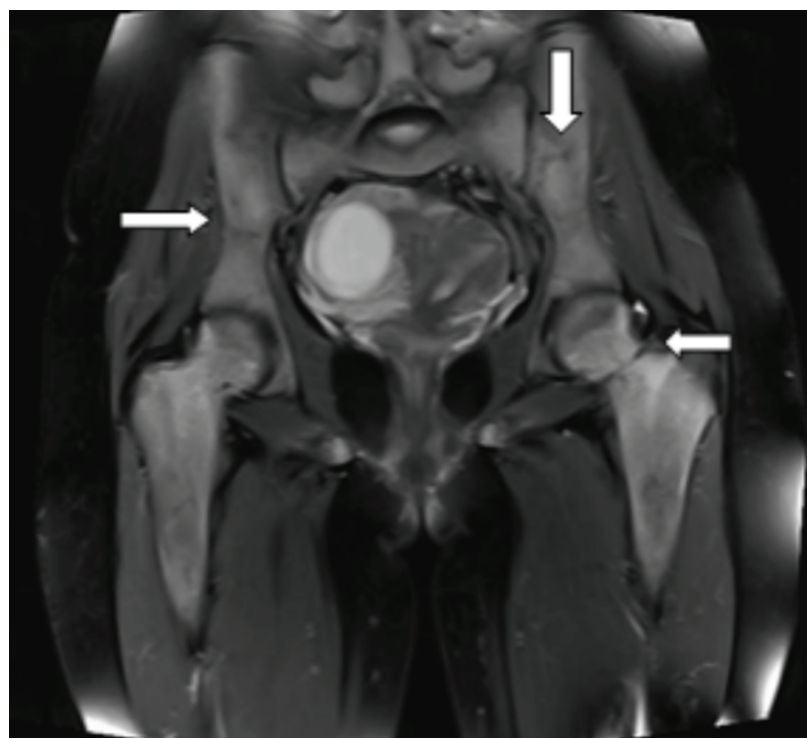

Figure 1b. Magnetic resonance coronal T2- weighted Fat-Sat image

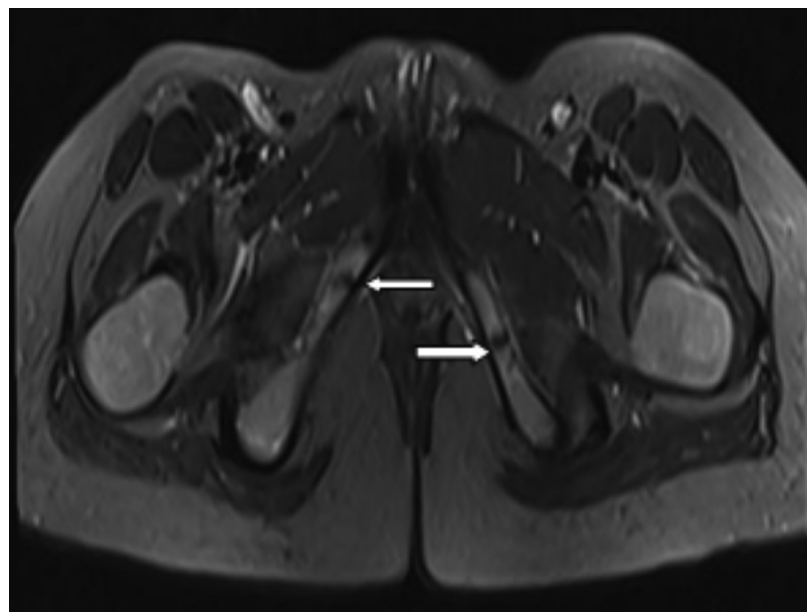

Figure 1c. Magnetic resonance axial T2- weighted image
$\mathrm{Ca}$, and secondary PTH elevation, and detection of multiple stress fractures in sacral MRI. one thousand two hundred milligrams of Ca and 50,000 IU of oral vitamin D per week were started for eight weeks. The patient was advised to have exposure to the sun, and nutrition and exercise recommendation were made.

\section{Discussion}

The diagnosis of osteomalacia is depends on the clinical, laboratory, and radiologic findings of the patient. Osteomalacia can be asymptomatic or radiologically appear as osteopenia. It may also cause typical symptoms, regardless of underlying causes such as extensive joint and bone pain, muscle weakness, and walking difficulty (1-4).

It was reported that among 17 patients who were diagnosed as having osteomalacia via bone biopsy, bone pain and muscle weakness was present in 16 (94\%), bone tenderness in 15 (88\%), fracture in 13 (76\%), walking difficulty and Trendelenburg gait (24\%), muscles pasms, cramps and positive Chvostek sign (12\%), and prickling sensation, drowsiness and difficulty in movement was present in (6\%) (5).

Bone pain is generally evident in the lower spine, pelvis and lower extremities with fractures, and palpation reveals severe tenderness. Pain can be increased by activity and weightbearing. Fractures can typically arise without mild trauma or no trauma, includin gribs, vertebrae and longbones. Muscle weakness is characteristic of the proximal muscles of the extremities and muscle loss may be accompanied by hypotonia $(1,6)$.

In retrospective analyses of patients with definite nutritional osteomalacia diagnosed through biopsy, elevated ALP (95$100 \%)$, decreased in serum Ca and P concentrations (27-38\%), decreased urinary $\mathrm{Ca}(87 \%)$, and $25(\mathrm{OH}) \mathrm{D}$ concentrations at $15 \mathrm{ng}(100 \%)$, and increased PTH concentrations (100\%) were observed $(1,4)$. Vitamin D deficiency due to insufficient vitamin $D$ intake, insufficient exposure to sunlight and malabsorption of vitamin $D$ is the most widespread cause of osteomalacia (1-3). Clinical evaluations such as gastrointestinal system diseases, sun exposure, dietary habits, and duration of initial symptoms (insidious or acute) may help to determine the etiology of osteomalacia (1-3). Vitamin D deficiency causes secondary hyperparathyroidism by reducing the absorption of $\mathrm{Ca}$ and phosphate in the intestine. Bone destruction, renal phosphate excretion, and renal tubular Ca reabsorption increase $(1,2,7)$.

Vitamin D support results in a dramatic improvement in muscle strength and bone sensitivity with in weeks. The effect of vitamin $D$ is usually most pronounced when there is sufficient Ca intake at the same time. Bone mineral density (BMD) may improve with in three to six months (7). Ca concentrations and urinary $\mathrm{Ca}$ excretion should be monitored at 1 month and 3 months in the treatment of osteomalacia. It should then be monitored less frequently (every 6 to 12 months) until the 24-hour urinary excretion is normal. Serum Ca concentrations should be monitored for the early detection of hypercalcemia. 
Serum 25(OH)D should be measured nearly 3 to 4 months after starting treatment. The doses hould be adjusted to prevent hypercalciuria or hypercalcemia. In most cases, serum Ca and phosphate are normal after a few weeks of treatment, but ALP may remain high for several months. Urinary Ca excretion and an increase in BMD are thought to improve osteomalacia. Osteomalacia may take a year or more to cure.The recovery time depends on the degree and duration of the deficiency (8).

For patients with severe vitamin $D$ deficiency $[25(\mathrm{OH}) \mathrm{D}<10$ $\mathrm{ng} / \mathrm{mL}(25 \mathrm{nmol} / \mathrm{L})]$, a common approach is to treat with oral 50,000 IU D2 or D3 weekly for 6 to 8 weeks, and then it is recommended to maintain with 800 IUof vitamin D3 daily (9). Patients with gastric bypass or malabsorption may require a dosage of 10,000 to 50,000 IU/day of vitamin D.

In liver-related diseases, vitamin $D$ metabolite calcidiol should be used because it does not require 25-hydroxylation. The onset of action is faster. In this case, th edose is 50 to 200 micrograms/ day $(1,2,5,9)$.

Osteomalacia should be kept in mind in patients with generalized pain, Trendelenburg gait, and vitamin D deficiency.

\section{Ethics}

Informed Consent: Informed consent form was obtained from all patients included in our study.

Peer-review: Internally peer-reviewed.

\section{Authorship Contributions}

Surgical and Medical Practices: B.O., Concept: B.O., Design: B.O., Data Collection or Processing: B.O., K.U., Analysis or
Interpretation: B.O., K.U., H.U., Literature Search: B.O., K.U., H.U., Writing: B.O.

Conflict of Interest: No conflict of interest was declared by the authors.

Financial Disclosure: The authors declared that this study received nof inancial support.

\section{References}

1. Bhan $A$, Rao $A D$, Rao DS. Osteomalacia as a result of vitamin $D$ deficiency. Endocrinol Metab Clin North Am 2010;39:321-31.

2. Cohen A, Drake MT. Clinical manifestations, diagnosis, and treatment of osteomalacia. http//www.uptodate.com//2017.

3. Fidan F, Alkan BM, Tosun A. Çağın pandemisi: D vitamini eksikliği ve yetersizliği. Turk J Osteoporos 2014;20:71-4.

4. Gifre L, Peris P, Monegal A, Martinez de Osaba MJ, Alvarez L, Guanabens N. Osteomalaciarevisited: a report on 28 cases. Clin Rheumatol 2011;30:639-45.

5. Basha B, Rao DS, Han ZH, Parfitt AM. Osteomalacia due to vitamin $D$ depletion: a neglected consequence of intestinal malabdorption. Am J Med 2000;108:296-300.

6. Lips P, van Schoor NM, Bravenboer N. Vitamin D-related disorders. In: Rosen CJ, editor. Primer on the Metabolic Bone Diseases and Disorders of Mineral Metabolism. 8th ed. UK, John Wiley\&Sons; 2013.

7. Bhambri R, Naik V, Malhotra N, Taneja S, Rastogi S, Ravishanker $\mathrm{U}$, et al. Changes in bone mineral density following treatment of osteomalacia. J Clin Densitom 2006;9:120-7.

8. Allen SC, Raut S. Biocemical recovery time scales in elderly patients with osteomalacia. J R Soc Med 2004;97:527-30.

9. Dawson-Hughes B. Vitamin D deficiency in adults: Definition, clinical manifestations, and treatment. http//www.uptodate. $\mathrm{com} / / 2019$. 